\title{
Electrical Performance Prediction of Line-Focus Fresnel Concentrating PV Module Based on Matlab Algorithm
}

\author{
Mengya Zhang, Hongbo Li, Xiaojun Ye, and Ning Yang
}

\begin{abstract}
Line-focus Fresnel concentrating PV module can improve the power efficiency because of concentration ratio growing. But there is another problem which non-uniform illumination can influence electrical performance parameters, such as short-circuit current Isc, open-circuit voltage Voc, fill factor FF and power efficiency $\eta$. How to assess the electric performance of non-uniform PV module is becoming an awkward problem. The whole equivalent circuit, including the darker and brighter PV parts, was analyzed. And electric performance forecasting algorithm was designed by MATLAB software according to equivalent circuit and basic principle of solar cell. In the end, actual electric performance of Line-focus Fresnel concentrating PV module was characterized by SourceMeter ® instrument. The characterization shows that actual testing results were in accordance with forecasting algorithm.
\end{abstract}

Index Terms-Non-uniform illumination, line focus fresnel concentrating PV module, electrical performance, MATLAB algorithm.

\section{INTRODUCTION}

Since oil crisis in 1973, concentrating photovoltaics (CPV) system seems to be needed to solve energy shortage. Ref. [1] Lots of institutes and corporations started to establish CPV programs. Amonix developed a point-focus concentrating PV system. Ref. [2] BP solar constructed linear reflective concentrating PV system with the help of EUCLIDES. Ref. [3] Entech invented the line-focus Fresnel lens which were used in space exploration and terrestrial station. Besides, a large amount of experiments and actual verification promoted the development of the terrestrial line-focus Fresnel CPV, from Sunline $₫$ to Sunrow $®$. Ref. [4] However, until now CPV technology still did not gain the needed momentum due to several reasons [5], including accuracy of tracking system, design of optical elements, difficulties of installation. With the development of CPV technology, the electrical performance of non-uniform concentrating PV module with different focusing elements were studied and applied widely. As we all know, concentrator optics, shape errors of concentrator profile, improper tracking, mechanical failures and spectral response can result in non-uniform illumination, which will affect

Manuscript received August 22, 2016; revised December 12, 2016.

Mengya Zhang is with the East China University of Science and Technology, Shanghai, CO 200237, China. She is also with Shanghai Solar Energy Research Center, Shanghai, CO 200241, China (e-mail: marciazhang@126.com)

Hongbo $\mathrm{Li}$, Xiaojun $\mathrm{Ye}$, and Ning Yang are with the East China University of Science and Technology, Shanghai, CO 200237, China (e-mail: lihongbo@ecust.edu.cn, 18817507313@163.com). many characteristics of solar cell tremendously, such as equivalent circuit, power efficiency, temperature distribution, lifetime and so on. [6] Franklin and Coventry [7] studied the effects of non-uniformity on the I-V characteristics of the solar cell both numerically and experimentally. They also demonstrated I-V characteristics differing from that of the reference cell at the same number of suns because of different losses in the metal grid [8]. A Luque [9] analyzed the heat transfer and equivalent circuit of linear reflective $\mathrm{CPV}$ module. And he presented that the module receiving inhomogeneous linear illumination, temperature drops showing Gaussian distribution and I-V curve changing slightly.

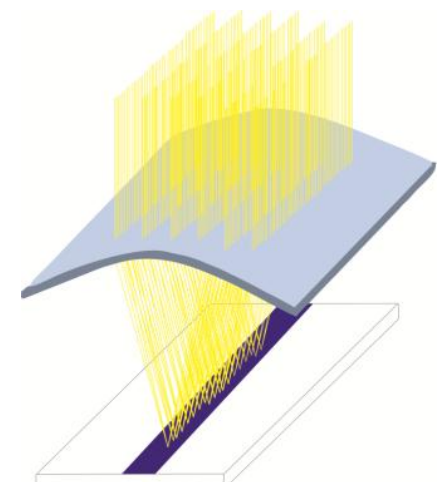

(a)

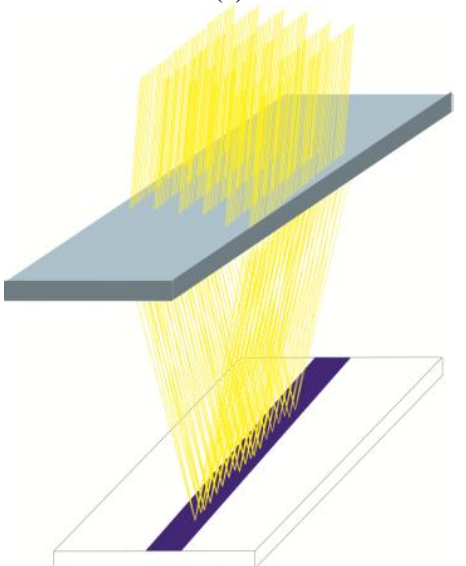

(b)

Fig. 1. Line-focus concentrating Fresnel PV module.

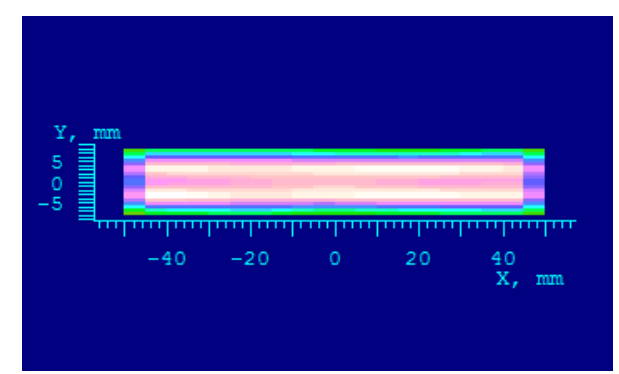

Fig. 2. Non-uniform illumination distribution of module. 


\section{EleCtric PERformance ForeCASTING Algorithm}

Line-focus Fresnel concentrating PV module is based on line-focus Fresnel lens, which can focus the sunlight on a linear solar cell as shown in Fig. 1. Due to transmission optical principle, the surface of solar cell can receive non-uniform illumination. As shown in Fig. 2, illumination intensity in the middle of battery is higher than edges. Therefore, not only the power generation changes but also other performance of solar cell, including temperature distribution, short-circuit current, open-circuit voltage, maximum power, and fill factor, changes dramatically.

In this article, equivalent circuit of line-focus concentrating PV module is analyzed based on basic photovoltaic principle. After I-V model being derived, electrical performance forecasting algorithm of modules, including traditional PV module and line-focus Fresnel concentrating PV module, are established by MATLAB software. In order to prove accuracy of I-V model and the algorithm, I-V curve of line-focus Fresnel concentrating PV

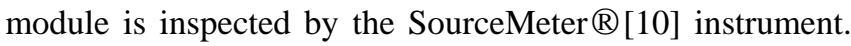
Model and forecasting algorithm are amended and optimized based on the testing results afterwards. Eventually, on the basis of forecasting algorithm, primary factors which can influence electrical performance of non-uniform illuminated PV modules are analyzed.

\section{A. Equivalent Circuit of Line-Focus Concentrating Module}

The receiver used in this study is laminated into module and consists of crystalline silicon solar cell, whose effective area is $2.5 \mathrm{~cm} \times 7.8 \mathrm{~cm}$. The solar cell can be divided into darker part and illuminated one.

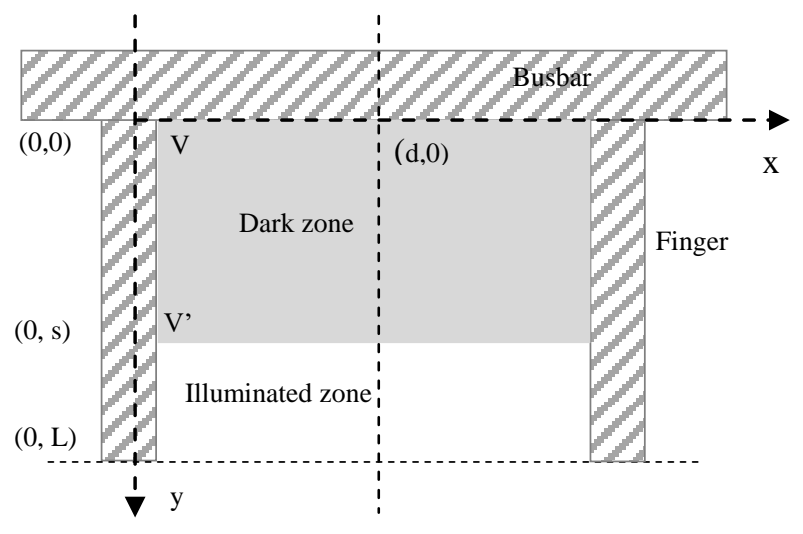

Fig. 3. Solar cell under uneven illumination.

There are three primary reasons why the line-focus Fresnel concentrating module is diverse from the traditional flat PV module. With concentration ratio growing, electrical performance, including open-circuit voltage, short-circuit current, power efficiency and fill factor value, increases significantly. Moreover, non-uniform illumination can cause uneven temperature distribution, which influences electrical performance. Finally, the series resistance of higher illumination area shows a slight increase and fill factor value decreases instead. In the meantime, dark diode effect appears in lower illumination area, which can't generate the photocurrent but result in electron recombination. Besides, because of chromatic dispersion of optical transmission elements, spectra distribution on receiver is no longer uniform. But it isn't taken into account in this article.

In terms of basic photovoltaic principle of solar cell and line reflective features, Luque A [9] deduced the formula of voltage, resistance and current, as shown in formula (1), (2), (3). The focusing characteristics of line-focus Fresnel concentrating PV module is similar with the linear reflective one, both of whom can focus sunlight into linear facula. Consequently, these formulas can be used in analysis of line-focus concentrating PV module.

$$
\begin{gathered}
I_{L}=J_{d} l d=J_{p h} l d-J_{L o} l d \bullet \exp \left\lfloor\frac{q\left(V^{\prime}+I_{L} R_{L s}\right)}{k T}\right\rfloor \\
V^{\prime}=V+R_{D t}^{\prime} I_{D}+R_{L s}^{\prime} I_{L} \\
R_{L s}=\frac{1}{3} R_{e} \frac{d}{l}+\frac{1}{3} R_{m} \frac{l}{\omega}+\rho_{B} \frac{\varepsilon}{l d}+\frac{r_{c}}{\omega l}
\end{gathered}
$$

$l$ and $d$ are the width of illumination area and width between two fingers respectively. And $R_{L s}$ is the series resistance under illumination. $J_{p h}$ is the photovoltaic current density and $J_{L O}$ is saturated current density without illumination. $V^{\prime}$ is the voltage at intersection of illumination area and dark area, as $(\mathrm{s}, 0)$ position shown in Fig. 3. $I_{L}$ is the current of series and $I_{D}$ is the inverse current of darkness. $R_{D t}^{\prime}$ and $R_{L s}^{\prime}$ are the metal finger resistance of darkness and illumination area. $q$ is quantity of electricity, $k$ is Boltzmann constant and $T$ is thermodynamic temperature, and the calculation method and parameters of sample as the Table I follows. Besides, the first part of formula (3) is emitter sheet resistance, the second one is metal finger resistance, third part is base resistance and the fourth one is contact resistance fingers. In conclusion, the equivalent circuit of solar module can change from basic solar cell principle to non-uniform one, as shown in Fig. 4 and Fig. 5.

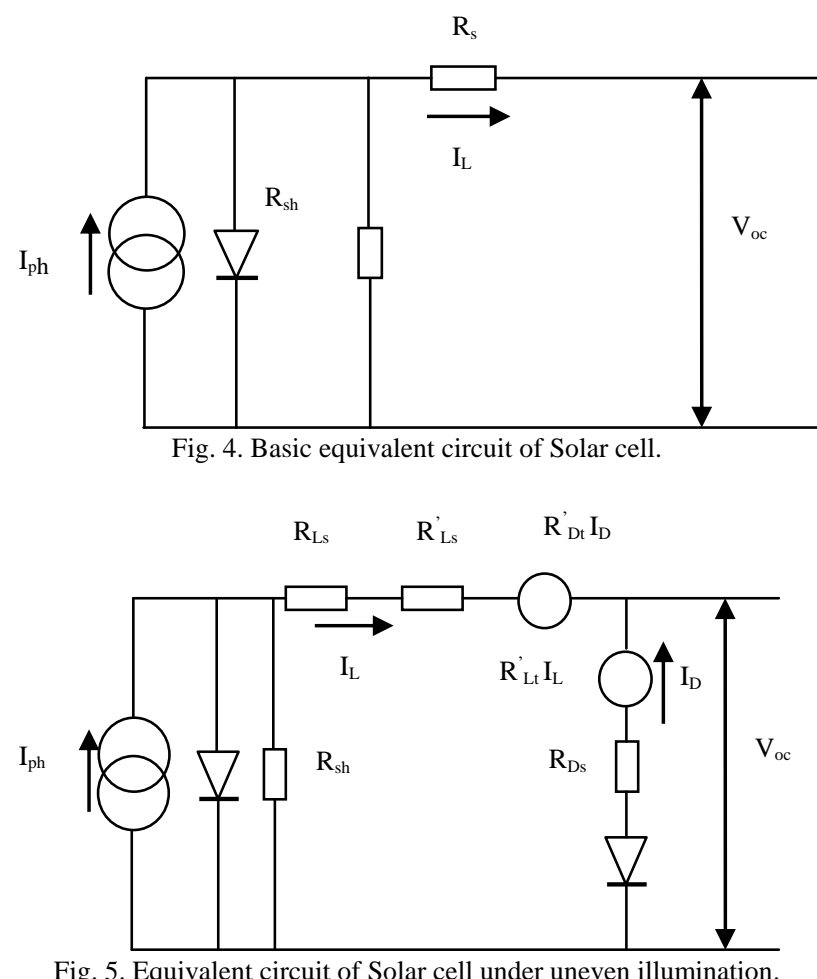

Fig. 5. Equivalent circuit of Solar cell under uneven illumination. 
TABLE I: PARAMETER OF CONCENTRATION MODULE

\begin{tabular}{|c|c|c|}
\hline Parameters & Expression & Value \\
\hline $\begin{array}{c}\text { Width of illumination } \\
\text { area }\end{array}$ & 1 & $0.6 \mathrm{~cm}$ \\
\hline Width of dark area & $\mathrm{s}$ & $0.65 \mathrm{~cm}$ \\
\hline $\begin{array}{l}\text { Distance between two } \\
\text { fingers }\end{array}$ & d & $0.04 \mathrm{~cm}$ \\
\hline Width of two fingers & w & $0.004 \mathrm{~cm}$ \\
\hline Thickness of solar cell & $\varepsilon$ & $0.03 \mathrm{~cm}$ \\
\hline Groove's depth & $\mathrm{g}$ & $0.005 \mathrm{~cm}$ \\
\hline Resistivity of $\mathrm{Si}$ & $\rho_{\mathrm{b}}$ & $0.3 \Omega \mathrm{cm}$ \\
\hline Resistivity of $\mathrm{A}_{\mathrm{g}}$ & $\rho \mathrm{A}_{\mathrm{g}}$ & $1.65 \times 10^{-5} \Omega \mathrm{cm}$ \\
\hline Emitter resistance & $\mathrm{Re}$ & $90 \Omega$ \\
\hline Metal sheet resistance & $\mathrm{Rm}=\rho \mathrm{A}_{\mathrm{g}} / \mathrm{g}$ & $0.0033 \Omega$ \\
\hline Body resistance & $\rho_{\mathrm{b}} \varepsilon$ & $0.009 \Omega$ \\
\hline $\begin{array}{l}\text { Fingers' resistance under } \\
\text { illumination }\end{array}$ & $\mathrm{Rml} 2 \mathrm{~d} / 3 \mathrm{w}$ & $3.96 \times 10^{-4} \Omega$ \\
\hline Illuminated area & AL & $9.36 \mathrm{~cm}^{2}$ \\
\hline Dark area & $\mathrm{AD}$ & $10.14 \mathrm{~cm}^{2}$ \\
\hline $\begin{array}{l}\text { Series resistance under } \\
\text { illumination } \mathrm{R}_{\mathrm{Ls}}\end{array}$ & $\begin{array}{c}\left(\mathrm{R}_{\mathrm{ed}} 2 / 3+\rho_{\mathrm{b}} \varepsilon+\mathrm{R}_{\mathrm{ml}} 2 \mathrm{~d} / 3 \mathrm{w}\right) / \\
\mathrm{AL}\end{array}$ & $0.0061 \Omega$ \\
\hline $\begin{array}{l}\text { Metal finger resistance } \\
\text { under illumination } \mathrm{R}_{\mathrm{Ls}}\end{array}$ & $\mathrm{R}^{\prime} \mathrm{Ls}=\left(\mathrm{R}_{\mathrm{ml}} \mathrm{s} / \mathrm{w}\right) / \mathrm{AL}$ & $1.375 \times 10^{-4} \Omega$ \\
\hline $\begin{array}{l}\text { Series resistance under } \\
\text { darkness } \mathrm{R}_{\mathrm{Dt}}^{\prime}\end{array}$ & $\mathrm{R}^{\prime}{ }_{\mathrm{Dt}}=\left(\mathrm{R}_{\mathrm{ms}} 2 \mathrm{~d} / 2 \mathrm{w}\right) / \mathrm{AD}$ & $6.875 \times 10^{-5} \Omega$ \\
\hline Series resistance Rs & $\begin{array}{c}\left(\mathrm{R}_{\mathrm{ed}} 2 / 3+\rho_{\mathrm{b}} \varepsilon+\mathrm{R}_{\mathrm{m}} \mathrm{L} 2 \mathrm{~d} / 3 \mathrm{w}\right) / \\
\mathrm{AL}\end{array}$ & $0.0063 \Omega$ \\
\hline $\begin{array}{l}\text { Shunt resistance under } \\
\text { darkness } \mathrm{R}_{\mathrm{sh} 1}\end{array}$ & 1 & $2.1 \Omega$ \\
\hline $\begin{array}{l}\text { Shunt resistance under } \\
\text { illumination } \mathrm{R}_{\mathrm{sh} 2}\end{array}$ & / & $1.925 \Omega$ \\
\hline $\begin{array}{l}\text { Photovoltaic current of } \\
\text { traditional solar cell } \mathrm{I}_{\mathrm{ph}}\end{array}$ & / & $0.46 \mathrm{~A}$ \\
\hline $\begin{array}{l}\text { Photovoltaic current of } \\
\text { CPV module } \mathrm{I}_{\mathrm{ph}}\end{array}$ & / & $0.658 \mathrm{~A}$ \\
\hline
\end{tabular}

\section{B. Establishment of Molding and Algorithm}

$$
\begin{gathered}
I_{L}=I_{p h}-I_{01} \bullet \exp \left\lfloor\frac{q\left(V+I_{L} R_{s}\right)}{n_{1} k T}\right\rfloor-I_{02} \bullet \exp \left\lfloor\frac{q\left(V+I_{L} R_{s}\right)}{n_{2} k T}\right\rfloor-\frac{U_{D}}{R_{s h 1}} \\
U_{D}=V+I_{L} R_{s} \\
I_{L}=I_{p h}-I_{01} \bullet \exp \left\lfloor\frac{q\left(V+I_{L} R_{L s}+I_{L} R_{L s}^{\prime}+I_{D} R_{D t}^{\prime}\right)}{n_{1} k T}\right\rfloor- \\
I_{02} \bullet \exp \left[\frac{q\left(V+I_{L} R_{L s}+I_{L} R_{L s}^{\prime}+I_{D} R_{D t}^{\prime}\right)}{n_{2} k T}\right\rfloor-\frac{U_{D}}{R_{s h 2}} \\
U_{D}=V+I_{L} R_{L s}+I_{L} R_{L s}^{\prime}+I_{D} R_{D t}^{\prime}
\end{gathered}
$$

According to the equivalent circuit of traditional solar cell and line-focus refractive concentrating PV module, mathematic model and logical algorithm have been designed and established. Flow chart of forecasting algorithm is shown in Fig. 6.

\section{Inspection and Optimization}

In this section, in order to measure and verify the modeling of line-focus concentrating electrical performance via field experiment, outdoor testing module was put up. This field experiment under the irradiance being at $746-801 \mathrm{~W} / \mathrm{mm}^{2}$ mainly focused on electrical performance which was resulted in by non-uniform concentrating light. Small outdoor testing module, SourceMeter $\mathbb{B}$ instrument and irradiance meter were used in this experiment process, as shown in Fig. 7.

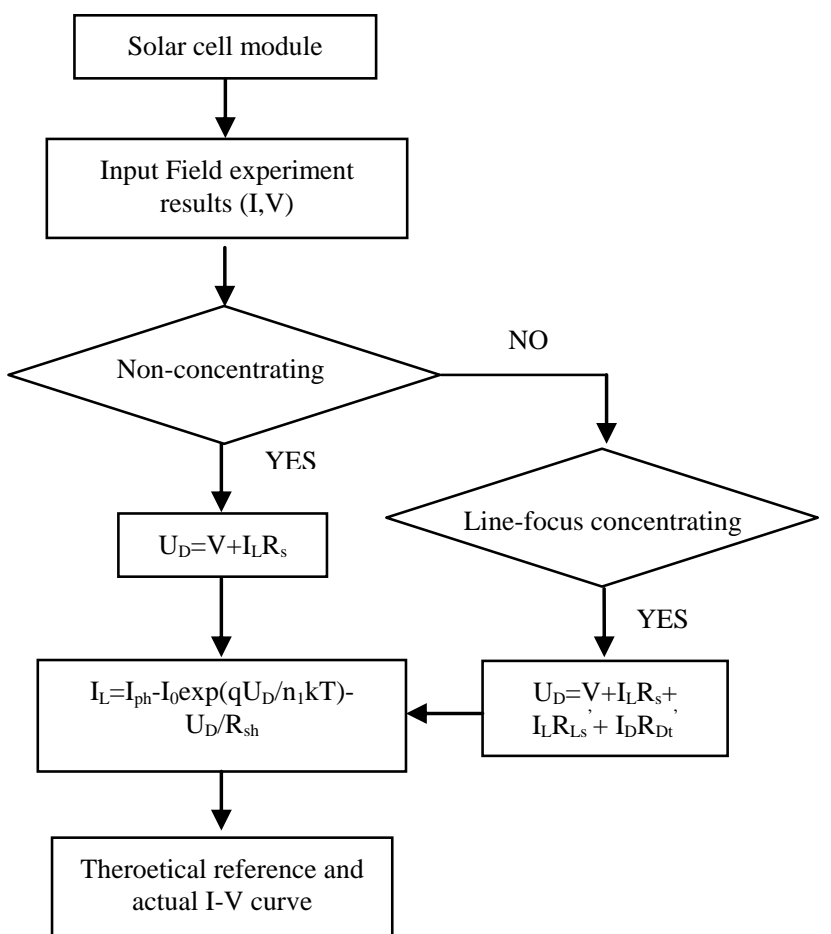

Fig. 6. The flow chart of electrical performance forecasting algorithm.

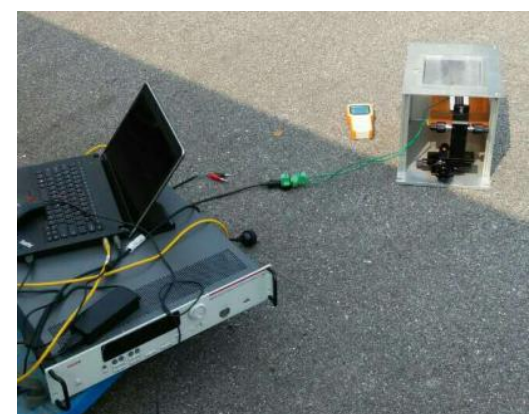

Fig. 7. Outdoor experiments.

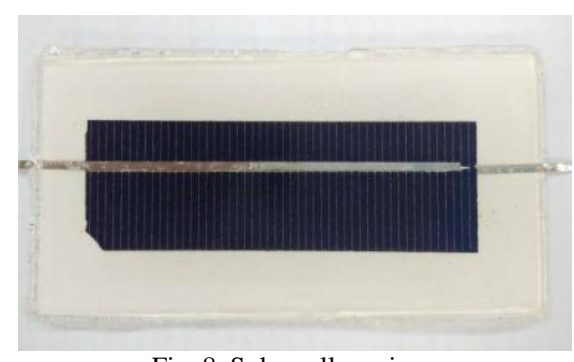

Fig. 8. Solar cell receiver

To begin with, small outdoor testing module is composed of adjustable optical platform, concentrating lens and solar cell receiver. Adjustable optical platform is established to match up with Fresnel lens and solar cell receiver. Whereby, receiver is silicon solar cell whose size is $7.8 \mathrm{~cm} \times 2.5 \mathrm{~cm}$, as shown in Fig. 8, and laminated into a micro photovoltaic module so as to protect the solar cell from damage. And flat line-focus Fresnel lens used in outdoor testing module is made from PMMA, the size of which is $140 \mathrm{~mm} \times 180 \mathrm{~mm}$ and focal length is $140 \mathrm{~mm}$. 
Afterwards, with irradiance signals being collected real-timely via irradiance meter, electrical performance of non-concentrating solar cell module and line-focus concentrating solar cell receiver were tested respectively using SourceMeter ${ }^{\circledR}$ instrument.

\section{RESUlTS AND DisCUSSION}

The electrical performance of traditional and line-focus concentrating solar cell module were tested in the above section. And its testing outcome of module under different irradiance has a little distinction, as shown in Table II and Table III. In addition, we set up a electrical performance forecasting algorithm of line-focus Fresnel concentrating module based on Luque A's molding and verify validity of our algorithm via field experiment outcome.

TABLE II: THE ELECTRICAL PERFORMANCE OF NON-CONCENTRATING PV MODULE UNDER AT $764 \mathrm{~W} / \mathrm{MM}^{2}$

\begin{tabular}{ccccc}
\hline \hline $\begin{array}{c}\text { Irradiance } \\
\left(\mathrm{W} / \mathrm{mm}^{2}\right)\end{array}$ & $\begin{array}{c}\mathrm{I}_{\mathrm{sc}} \\
(\mathrm{A})\end{array}$ & $\begin{array}{c}\mathrm{V}_{\mathrm{oc}} \\
(\mathrm{V})\end{array}$ & $\begin{array}{c}\text { Voltage } \\
(\mathrm{V})\end{array}$ & $\begin{array}{c}\text { Current } \\
(\mathrm{A})\end{array}$ \\
\hline & & & 0 & 0.372998 \\
& & & 0.102041 & 0.340423 \\
746 & 0.372998 & \multirow{2}{*}{0.538281} & 0.204082 & 0.305373 \\
& & & 0.306123 & 0.264709 \\
& & & 0.408163 & 0.21071 \\
& & & 0.510204 & 0.085201 \\
\hline \hline
\end{tabular}

TABLE III: The Electrical PeRformance of Non-CONCENTRATING PV MODULE UNDER AT $801 \mathrm{~W} / \mathrm{MM}^{2}$

\begin{tabular}{|c|c|c|c|c|}
\hline $\begin{array}{l}\text { Irradiance } \\
\left(\mathrm{W} / \mathrm{mm}^{2}\right)\end{array}$ & $\begin{array}{l}\mathrm{I}_{\mathrm{sc}} \\
\text { (A) }\end{array}$ & $\begin{array}{l}\mathrm{V}_{\mathrm{oc}} \\
(\mathrm{V})\end{array}$ & $\begin{array}{c}\begin{array}{c}\text { Voltage } \\
(\mathrm{V})\end{array}\end{array}$ & $\begin{array}{l}\text { Current } \\
\text { (A) }\end{array}$ \\
\hline \multirow{6}{*}{801} & \multirow{6}{*}{0.459066} & \multirow{6}{*}{0.548802} & 0 & 0.459066 \\
\hline & & & 0.102041 & 0.4159 \\
\hline & & & 0.204082 & 0.371628 \\
\hline & & & 0.306123 & 0.323372 \\
\hline & & & 0.408163 & 0.256914 \\
\hline & & & 0.510204 & 0.105458 \\
\hline
\end{tabular}

TABLE IV: THE ELECTRICAL PERFORMANCE OF NON-CONCENTRATING PV MODULE UNDER AT $751 \mathrm{~W} / \mathrm{MM}^{2}$

\begin{tabular}{ccccc}
\multicolumn{5}{c}{ MODULE UNDER AT 751 W/MM } \\
\hline \hline $\begin{array}{c}\text { Irradiance } \\
\left(\mathrm{W} / \mathrm{mm}^{2}\right)\end{array}$ & $\mathrm{I}_{\mathrm{sc}}$ & $\mathrm{V}_{\mathrm{oc}}$ & Voltage & Current \\
& $(\mathrm{A})$ & $(\mathrm{V})$ & $(\mathrm{V})$ & $(\mathrm{A})$ \\
\hline & & & 0 & 0.377421 \\
& & & 0.102041 & 0.334539 \\
751 & \multirow{3}{*}{0.377421} & 0.538281 & 0.204082 & 0.290647 \\
& & & 0.306123 & 0.243718 \\
& & & 0.408163 & 0.18442 \\
& & & 0.510204 & 0.063542 \\
\hline \hline
\end{tabular}

Field experiment outcome of non-concentrating PV module is shown in Table II, III, IV from which we can obtain the short-circuit current $I_{s c}$, open-circuit voltage $V_{\text {oc }}$ and their corresponding relationship. To begin with, short-circuit current $I_{s c}$ and open-circuit voltage $V_{o c}$ at 746 $\mathrm{W} / \mathrm{mm}^{2}$ is close to the value at $751 \mathrm{~W} / \mathrm{mm}^{2}$. However, compared with above two experiment results, the traditional module under irradiance at $801 \mathrm{~W} / \mathrm{mm}^{2}$ exhibit a larger $\mathrm{I}_{\mathrm{sc}}$ and $\mathrm{V}_{\text {oc }}$. In consequence, irradiance has a positive impact on electrical performance.

And Table V, VI, VII are the field experiment outcomes of line-focus concentrating PV module. It indicates that short-circuit current $I_{s c}$ and open-circuit voltage $V_{o c}$ at 746
$\mathrm{W} / \mathrm{mm}^{2}$ is close to the value at $751 \mathrm{~W} / \mathrm{mm}^{2}$ and irradiance mainly affects short-circuit current of line-focus Fresnel PV module. When irradiance being improved from $746 \mathrm{~W} / \mathrm{mm}^{2}$ to $801 \mathrm{~W} / \mathrm{mm}^{2}$, short-circuit current increased by $42.354 \mathrm{~mA}$, but open-circuit voltage remained unchanged.

Besides, I-V curve has an enormous difference between traditional photovoltaic module and line-focus Fresnel concentrating module, as shown in Fig. 8. Picture (a), (b) and (c) of Fig. 9 indicate that I-V curve of line-focus Fresnel concentrating PV module is similar with traditional one, but its short-circuit current and open-circuit voltage is larger than traditional one.

TABLE V: THE ElECTRICAL PERFORMANCE OF LINE-FOCUS CONCENTRATING PV MOdULE AT $764 \mathrm{~W} / \mathrm{MM}^{2}$

\begin{tabular}{|c|c|c|c|c|}
\hline $\begin{array}{l}\text { Irradiance } \\
(\mathrm{W} / \mathrm{mm} 2)\end{array}$ & $\begin{array}{l}\mathrm{I}_{\mathrm{sc}} \\
\text { (A) }\end{array}$ & $\begin{array}{l}\mathrm{V}_{\mathrm{oc}} \\
(\mathrm{V}) \\
\end{array}$ & $\begin{array}{c}\text { Voltage } \\
(\mathrm{V})\end{array}$ & $\begin{array}{c}\text { Current } \\
\text { (A) }\end{array}$ \\
\hline \multirow{6}{*}{764} & \multirow{6}{*}{0.61334} & \multirow{6}{*}{0.563815} & 0 & 0.613348 \\
\hline & & & 0.102041 & 0.579432 \\
\hline & & & 0.204082 & 0.542329 \\
\hline & & & 0.306123 & 0.498754 \\
\hline & & & 0.408163 & 0.437372 \\
\hline & & & 0.510204 & 0.262737 \\
\hline
\end{tabular}

TABLE VI: THE ElECTRICAL PERFORMANCE OF LINE-FoCUS CONCENTRATING PV MODULE AT $801 \mathrm{~W} / \mathrm{MM}^{2}$

\begin{tabular}{|c|c|c|c|c|}
\hline $\begin{array}{c}\text { Irradiance } \\
\left(\mathrm{W} / \mathrm{mm}^{2}\right)\end{array}$ & $\begin{array}{l}\mathrm{I}_{\mathrm{sc}} \\
(\mathrm{A})\end{array}$ & $\begin{array}{l}\mathrm{V}_{\mathrm{oc}} \\
(\mathrm{V})\end{array}$ & $\begin{array}{c}\text { Voltage } \\
\text { (V) }\end{array}$ & $\begin{array}{c}\text { Current } \\
\text { (A) }\end{array}$ \\
\hline \multirow{6}{*}{801} & \multirow{6}{*}{0.655694} & \multirow{6}{*}{0.563815} & 0 & 0.655694 \\
\hline & & & 0.102041 & 0.612428 \\
\hline & & & 0.204082 & 0.566963 \\
\hline & & & 0.306123 & 0.513338 \\
\hline & & & 0.408163 & 0.4202 \\
\hline & & & 0.489796 & 0.249892 \\
\hline
\end{tabular}

TABLE VII: THE ELECTRICAL PERFORMANCE OF LINE-FOCUS CONCENTRATING Pv MOdULE AT $751 \mathrm{~W} / \mathrm{MM}^{2}$

\begin{tabular}{ccccc}
\hline \hline $\begin{array}{c}\text { Irradiance } \\
\left(\mathrm{W} / \mathrm{mm}^{2}\right)\end{array}$ & $\mathrm{I}_{\mathrm{sc}}$ & $\mathrm{V}_{\mathrm{oc}}$ & Voltage & $\begin{array}{c}\text { Current } \\
(\mathrm{A})\end{array}$ \\
\hline & & $(\mathrm{V})$ & $(\mathrm{V})$ & 0.612583 \\
& & & 0.102041 & 0.569179 \\
751 & 0.612583 & 0.557784 & 0.204082 & 0.524065 \\
& & & 0.306123 & 0.471572 \\
& & & 0.408163 & 0.383407 \\
& & & 0.510204 & 0.162266 \\
\hline \hline
\end{tabular}

According to photovoltaic principle of traditional solar cell and line-focus Fresnel concentrating solar cell, forecasting algorithm was established by MATLAB software to forecast and estimate their electrical performance. Then field experiments were carried out and results were obtained. Eventually, when field experiment results input and the algorithm operated, a theoretical reference curve and actual experimental scatter line are exhibited in the same figure, as shown in Fig. 9. Output of traditional solar cell shows a good agreement between theoretical reference curve and measured curve, which verify that forecasting algorithm of traditional solar cell is correct and accurate, as shown in picture (a) of Fig. 10.

Line-focus Fresnel solar cell has a specific concentrating characteristic that it can focus lights on a line and result in non-uniformity. On this account, uneven illumination of line-focus concentrating solar cell changes its equivalent circuit and the formula of photo-generated current so that its 
forecasting algorithm is different from the traditional one. With the aid of field experiment, a comparison between theoretical and actual results is given, shown in picture (b) of Fig. 9.

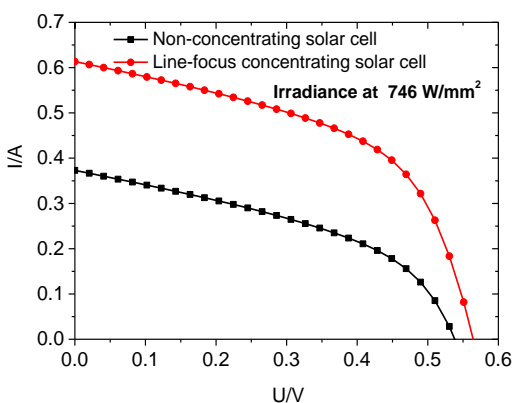

(a)

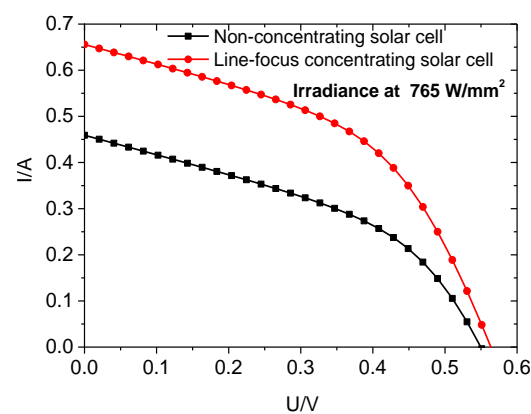

(b)

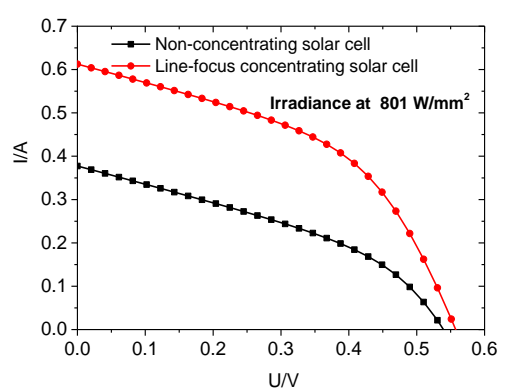

(c)

Fig. 9. I-V curve of non-concentrating concentrating module under different irradiance.

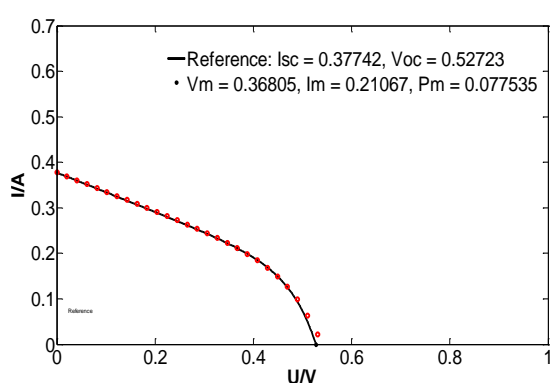

(a)

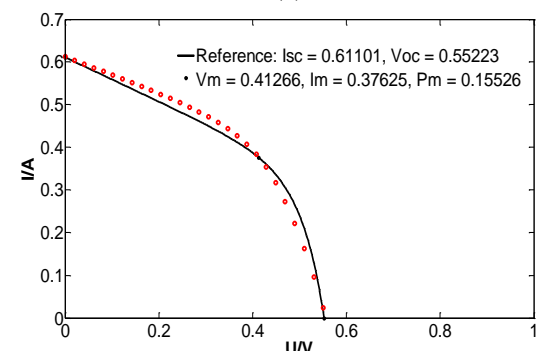

(b)

Fig. 10. The theoretical I-V curve model and actual result of flat module and concentration module.
In general, field testing outcome of both traditional solar cell and line-focus Fresnel concentrating solar cell corresponds with theoretical reference curve well. Although Fig. 10 indicates that forecasting algorithm of traditional solar cell and line-focus Fresnel concentrating solar cell are correct and accurate, forecasting algorithm of line-focus concentrating solar cell has slight deviation between theoretical and actual results. Hence it should be optimized further by modifying parameters in the formula of photo-generated current next step.

\section{CONCLUSION}

A review of the effects of the non-uniform illumination on concentrator solar cells has been presented. In this article, equivalent circuit and photo-generated current formula of traditional solar cell and line-focus Fresnel concentrating solar cell are analyzed in detail. Both traditional solar cell and line-focus Fresnel concentrating solar cell were tested via SourceMeter $\mathbb{B}$ instrument. Testing results shows that irradiance has impact on electrical performance of not only traditional solar cell but also line-focus Fresnel concentrating solar cell positively. In addition, electrical performance modeling and forecasting algorithm were established by MATLAB software. Owing to concentrating characteristic of line-focus Fresnel lens, there is non-uniform illumination on line-focus concentrating module. Although both field testing I-V curves fit theoretical reference curves well, actual and theoretical curves of line-focus concentrating module doesn't match as well as traditional one.

To sum up, forecasting algorithm and analysis set up can estimate electrical performance and were manifested validly. But electrical performance algorithm of line-focus Fresnel concentrating solar cell should be optimized further so that can correspond with the field testing results well and improve accuracy of prediction.

\section{ACKNOWLEDGMENT}

Mengya Zhang thanks Professor Xiao Yuan, Professor Cui Liu and Professor Guoqiang Hao who provided equipment and research funds for this research. Besides, thanks Yefei Ding and for help during this work.

\section{REFERENCES}

[1] G. Sala and I. Antón, "Photovoltaic concentrators," Handbook of Photovoltaic Science and Engineering, Chichester, UK: John Wiley \& Sons, 2011, ch. 11, pp. 402-451.

[2] T. Saifee and A. I. Konnerth, "Low-cost manufacturing of the point focus concentrating module and its key component, the Fresnel lens," NASA Sti/recon Technical Report N 92, 1991.

[3] M. J. O'Neill, A. J. Mcdanal, and P. A. Jaster, Development of Terrestrial Concentrator Modules Using High-Efficiency Multi-junction Solar Cells, ENTECH, Inc. Keller, TX, 2002, pp. 1369-1372.

[4] G. Sala, J. C. Arboiro, A. Luque, J. C. Zamorano, J. C. Min, and C. Dramsch, "The EUCLIDES prototype, an efficient parabolic trough for PV concentration," in Proc 25th Photovoltaic Specialists Conf. IEEE, New York, 1996, pp. 1207-1210.

[5] R. M. Swanson, "The promise of concentrators," Progress in Photovoltaics:Research and Applications, vol. 8, no. 1, pp. 93-111, April 2000.

[6] H. Baig, K. C. Heasman, and T. K. Mallick, "Non-uniform illumination in concentrating solar cells," Renewable \& Sustainable Energy Reviews, vol. 16, no. 8, pp. 5890-5909, June 2012. 
[7] E. Franklin and J. Coventry, "Effects of highly non-uniform illumination distribution on electrical performance of solar cells," Australian National University, 2002.

[8] K. A. Kerschen and P. A. Basore, "A performance model for nonuniformity Cilluminated front-gridded concentrator cells," Photovoltaic Specialists Conference, pp. 1129-1137, vol. 2, 1988.

[9] A. Luque, G. Sala, and J. C. Arboiro, "Electric and thermal model for non-uniformly illuminated concentration cells," Solar Energy Materials \& Solar Cells, vol. 51, no. 3-4, pp. 269-290, February 1998.

[10] Sourcemeter. [Online]. Available: http://www.tek.com/keithley-source-measure-units/keithley-smu-2650 -series-high-power-sourcemeter

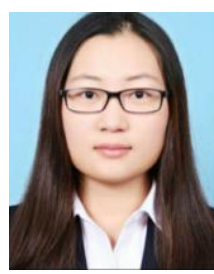

Mengya Zhang was born in October, 1990. She graduated from East China University of Science and Technology in Shanghai where she obtained her master degree in Material Engineering in January, 2016. She devoted to solar energy research, including concentrating solar module and quantum dots.

She works as an engineer in Solar Energy Research Center in Shanghai. 3 articles and 3 patents which she contributed to have been published before. She is interested in solar modules testing, testing standards research and project management. Ms. Zhang obtained Outstanding Poster Award in Chinese Sol-Gel conference.

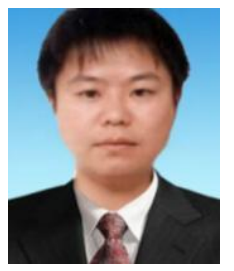

Hongbo Li was born in July, 1973. He graduated from Chinese Academy of Sciences in Shanghai where he obtained his $\mathrm{Ph} . \mathrm{D}$ degree in electronics science and technology in August, 2002.

He is professor in East China University and Science and Technology. 22 articles and 19 patents which he contributed to have been published. He devotes to solar energy research, including solar cells used in space, solar system, concentrating solar cell and testing equipment.

Professor $\mathrm{Li}$ achieved many awards like Shanghai Science and Technology Progress Award, Outstanding Academic Leader, Phosphor Science Foundation and so on. Besides he works as committee in solar energy academy, Chinese chemistry and physics power association and Chinese renewable energy academy as additional post.

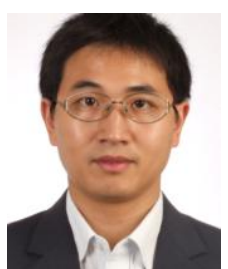

Xiaojun Ye was born in October, 1977. He graduated from Institute of Semiconductors, Chinese Academy of Sciences in Beijing where he obtained his PH.D degree in Micro-electronics and Solid-state Electronics in March, 2005.

$\mathrm{He}$ is associate professor in East China University of Science and Technology. He devotes to solar energy research, including thin film solar cells, heterojunction solar cells and testing equipment now.

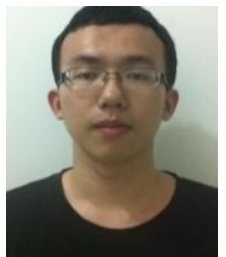

Ning Yang was born in October 1993. He obtained bachelor degree in new energy materials and devices at East China University of Science and Technology. Now he is studying for a doctor degree at East China University of Science and Technology majoring in silicon solar cells. 